\title{
Amlodipine Fatality in an Infant with Postmortem Blood Levels
}

\author{
Henry A. Spiller • Beth A. Milliner • George M. Bosse
}

Published online: 20 January 2012

(C) American College of Medical Toxicology 2012

\begin{abstract}
Introduction Amlodipine is a dihydropyridine calcium channel blocker used in the treatment of hypertension and angina pectoris. Toxic effects reported from amlodipine include hypotension, reflex tachycardia, metabolic acidosis, and pulmonary edema. We report a rare fatality in an infant after ingestion of amlodipine with benazepril, with postmortem blood concentrations.

Case report An 11-month-old, 10.88-kg boy ingested 10 to $45 \mathrm{mg}$ amlodipine with 40 to $180 \mathrm{mg}$ benazepril. No action was taken initially because the parents believed only one or two capsules had been ingested. A later count revealed a maximum of nine capsules missing. The child was observed at home and vomited once with possible capsule fragments. Forty-five minutes post-ingestion, the child was noted to be suddenly unresponsive and was brought the local emergency department by a private vehicle. Upon arrival (90 min postingestion), the child was unresponsive with the following vital signs HR 133 bpm, BP 67/42 mmHg, respiratory rate 40/min, and temperature $97.5^{\circ} \mathrm{F}$. Pertinent abnormal laboratory values were $\mathrm{HCO}_{3} 13 \mathrm{mmol} / \mathrm{l}$ and glucose $302 \mathrm{mg} / \mathrm{dl}$. The child was placed on oxygen via a non-rebreather mask and was intubated 45 min post-arrival. The patient became progressively
\end{abstract}

H. A. Spiller $(\bowtie)$

Kentucky Regional Poison Control Center

of Kosair Children's Hospital,

PO Box 35070, Louisville, KY 40232-5070, USA

e-mail: henry.spiller@nortonhealthcare.org

B. A. Milliner

Emergency Department, Saints' Mary and Elizabeth Hospital,

Louisville, KY, USA

G. M. Bosse

University of Louisville School of Medicine,

Louisville, KY, USA bradycardic, and $55 \mathrm{~min}$ after arrival, the patient was in asystole with no palpable blood pressure. Resuscitation measures included chest compressions, epinephrine atropine, sodium bicarbonate, and calcium gluconate. Rescue insulin therapy was begun with 4 units IVP followed by 10 units per hour. Resuscitation efforts persisted for $1 \mathrm{~h}$ without success. An autopsy revealed pulmonary edema and no gross or microscopic evidence of natural disease. Stomach contents revealed food matter with small white fragments. Analysis of postmortem heart blood showed amlodipine $1,300 \mathrm{ng} / \mathrm{ml}$ (therapeutic $<20 \mathrm{ng} / \mathrm{ml}$ ). Benazepril levels were not available. Discussion We believe this is the first reported fatality in an infant from amlodipine. While benazepril may have contributed, ACE inhibitors have not been previously associated with rapid cardiovascular collapse.

Conclusion Small doses of amlodipine ( 0.9 to $4.1 \mathrm{mg} / \mathrm{kg}$ ) may produce rapid and fatal cardiovascular collapse in an infant.

Keywords Amlodipine · Postmortem · Infant · Overdose

\section{Introduction}

Amlodipine is a dihydropyridine calcium channel blocker (CCB) used in the treatment of hypertension and angina pectoris [1]. As a second-generation dihydropyridine, amlodipine is more lipid soluble than the first-generation $\mathrm{CCB}$ (e.g., nifedipine) with a longer half life ( 30 to $55 \mathrm{~h}$ ). The slow clearance and long duration has allowed for once a day dosing. In animal studies, toxicity and death have occurred at doses equal to or greater than $4 \mathrm{mg} / \mathrm{kg}$. The dihydropyridine group of CCB shows greater selectivity for vascular calcium channels compared with cardiac cells with a lack of negative ionotropic effects at therapeutic dosing. Toxic effects reported from amlodipine include hypotension, reflex 
tachycardia, metabolic acidosis, and pulmonary edema [2-4]. We report a fatal overdose in an infant with postmortem amlodipine concentrations.

\section{Case Report}

An 11-month-old, 10.9-kg, previously healthy male arrived unresponsive to the emergency department (ED). The mother reported that the child was found at home with his grandmother's pill bottle approximately $90 \mathrm{~min}$ earlier. Initially, it was believed the child could have only ingested one to two pills of Lotrel $5 / 20{ }^{\circledR}$ (amlodipine $5 \mathrm{mg} /$ benazepril $20 \mathrm{mg}$ ), and it was decided by the family that the child will be monitored closely at home. A later pill count in the ED revealed up to nine pills missing. Approximately $45 \mathrm{~min}$ after ingestion, while still at home, the child vomited white material with possible capsules, became unresponsive, and was transported to the ED via a private vehicle. During transport, periods of apnea were noted by the family.

On physical exam, the child had the following vital signs: heart rate $133 \mathrm{bpm}$, blood pressure 67/42 $\mathrm{mmHg}$, respirations 40/min, and temperature $97.5 \mathrm{~F}$. The patient was lethargic, cyanotic, and responded with cry when stimulated. The patient's airway was open with clear and equal breath sounds on auscultation. Cardiac examination revealed tachycardia with no murmurs, rubs, or gallops. The abdomen was soft with no guarding. There were no signs of trauma. The patient was placed on a non-rebreather mask with $100 \%$ oxygen. An initial point of care/finger stick revealed a blood glucose of $339 \mathrm{mg} / \mathrm{dl}$. A complete blood count, comprehensive metabolic panel, coagulation studies, and urinalysis were obtained. Laboratory results were unremarkable except for a serum bicarbonate of $13 \mathrm{mmol} / \mathrm{L}$ and glucose of $302 \mathrm{mg} / \mathrm{dl}$. There was no history of diabetes. The patient's condition deteriorated shortly after arrival and preparations were made for transfer to a tertiary facility. No further labs were obtained due to the anticipated rapid transfer. Forty-five minutes after arrival, respirations became agonal and the patient was intubated. The poison control center was contacted for recommendations. The patient became progressively bradycardic, and 55 min after arrival, the patient was in asystole with no palpable blood pressure. Resuscitation efforts included chest compressions, epinephrine $(0.1 \mathrm{mg} \times 3)$, atropine $(0.2 \mathrm{mg} \times 2)$, sodium bicarbonate $(20 \mathrm{meq} \times 2)$, and calcium gluconate $(100 \mathrm{mg} \times 1)$. During resuscitation, approximately $30 \mathrm{~min}$ into the code, the patient received a bolus of insulin 4 units IV push $(0.36$ units $/ \mathrm{kg}$ ) followed by an infusion of 10 units/hour and epinephrine infusion in normal saline at $0.65 \mathrm{mg} / \mathrm{h}$. During resuscitation, a point of care/finger stick revealed a blood glucose of $224 \mathrm{mg} / \mathrm{dl}$. The patient did not respond to these measures and died $2 \mathrm{~h}$ after arrival.

An autopsy revealed pulmonary edema with intraalveolar hemorrhage without evidence of natural disease or

Table 1 Amlodipine ingestions with reported blood levels and outcome

\begin{tabular}{|c|c|c|c|c|}
\hline Age and gender & $\begin{array}{l}\text { Peak serum } \\
\text { amlodipine level }\end{array}$ & $\begin{array}{l}\text { Reported dose } \\
\text { ingested }\end{array}$ & Outcome & \\
\hline 11-month-old male & $1,300 \mathrm{ng} / \mathrm{ml}$ & $\begin{array}{l}10 \text { to } 45 \mathrm{mg} 0.9 \text { to } \\
4.1 \mathrm{mg} / \mathrm{kg}\end{array}$ & $\begin{array}{l}\text { Fatality, hypotension, tachycardia, refractory } \\
\text { shock }\end{array}$ & Present case \\
\hline 63-year-old female & $185 \mathrm{ng} / \mathrm{ml}$ & $70 \mathrm{mg}$ & $\begin{array}{l}\text { Fatality, hypotension, bradycardia, ventricular } \\
\text { dysrhythmias, refractory shock after } 24 \mathrm{~h}\end{array}$ & Koch et al. [8] \\
\hline 50-year-old male & $2,300 \mathrm{ng} / \mathrm{ml}$ (postmortem) & Unknown & Fatality, no clinical details available & Johansen et al. [11] \\
\hline 15-year-old female & $2,700 \mathrm{ng} / \mathrm{ml}$ (postmortem) & $140 \mathrm{mg}$ & Fatality, hypotension, tachycardia & Cosbey et al. [6] \\
\hline 44-year-old male & $\begin{array}{l}2,400 \mathrm{ng} / \mathrm{ml} \text { (postmortem } \\
\text { heart blood) }\end{array}$ & Unknown & Fatality, no clinical details available & Sklerov [10] \\
\hline 66-year-old female & $\begin{array}{l}870 \mathrm{ng} / \mathrm{ml} \text { (postmortem } \\
\text { peripheral blood) } \\
950 \mathrm{ng} / \mathrm{ml} \text { (postmortem } \\
\text { heart blood) }\end{array}$ & Unknown & Fatality, no clinical details available & Sklerov [10] \\
\hline Not listed & $940 \mathrm{ng} / \mathrm{ml}$ & Unknown & Fatality, also found velafaxine citalopram & Linnet et al. [9] \\
\hline 76-year-old male & $67 \mathrm{ng} / \mathrm{ml}$ & $100 \mathrm{mg}$ & $\begin{array}{l}\text { Survived, hypotention, acute renal failure, } \\
\text { pulmonary edema }\end{array}$ & Adams et al. [2] \\
\hline 43-year-old male & $143 \mathrm{ng} / \mathrm{ml}$ & $350 \mathrm{mg}$ & Survived, tachycardia & Poggenborg et al. [13] \\
\hline 42-year-old male & $393 \mathrm{ng} / \mathrm{ml}$ & $1,000 \mathrm{mg}$ & $\begin{array}{l}\text { Survived, hypotension, reduced ventricular } \\
\text { ejection fraction, pulmonary edema }\end{array}$ & Vogt et al. [14] \\
\hline 42-year-old female & $88 \mathrm{ng} / \mathrm{ml}$ & $50-100 \mathrm{mg}$ & $\begin{array}{l}\text { Survived, hypotension, tachycardia, } \\
\text { pulmonary edema }\end{array}$ & Staneck et al. [15] \\
\hline 22-year-old female & $150 \mathrm{ng} / \mathrm{ml}$ & $425 \mathrm{mg}$ & $\begin{array}{l}\text { Survived, hypotension, tachycardia, third degree } \\
\text { AV block, acute renal failure }\end{array}$ & Ezidiegwu et al. [16] \\
\hline 37-year-old male & $130 \mathrm{ng} / \mathrm{ml}$ & $6.7 \mathrm{mg} / \mathrm{kg}$ & $\begin{array}{l}\text { Survived, hypotension, bradycardia, third degree } \\
\text { AV block, also ingested atenaolol and alprazolam }\end{array}$ & Yuan et al. [23] \\
\hline
\end{tabular}


trauma. The patient's stomach contents contained less than $1 / 4$ cup of partially digested food and small white fragments (indefinite for pill fragment). The postmortem amlodipine heart blood level was reported as $1,300 \mathrm{ng} / \mathrm{ml}$. There were no other drugs or alcohol detected. Benazepril levels were not available.

\section{Results and Discussion}

There have been no previous reports of a fatal outcome after amlodipine ingestion in a young child $[3,5]$. Previous reported fatalities have occurred following intentional overdoses with suicidal intent; primarily in adults with a single pediatric fatality related to amlodipine overdose in a 15-year-old female [6-11] (see Table 1). The postmortem heart blood amlodipine concentration in our patient was $1,300 \mathrm{ng} / \mathrm{ml}$. This level is in the range of previous postmortem amlodipine concentrations after intentional large ingestions [6-11] (Table 1). Therapeutic levels of amlodipine are reported to be 1 to $24 \mathrm{ng} / \mathrm{ml}[1,9,12]$. Cases of amlodipine intoxication with survival reported amlodipine concentrations ranging from 67 to $393 \mathrm{ng} / \mathrm{ml}[2,13-16]$. Postmortem blood levels may not reflect circulating antemortem levels [17]. It is unknown if there is any significant postmortem redistribution with amlodipine. Although it is still unclear as to the amount of amlodipine ingested by our patient, the blood level suggests it was more than one capsule. The child in this case was initially believed to have ingested anywhere from $5-10 \mathrm{mg}$, but a pill count in the ED showed up to nine capsules (45 mg amlodipine) were missing from the pill bottle. Peak concentrations after therapeutic doses occur between 6 and $8 \mathrm{~h}$ post-ingestion and may be longer in overdose $[1,8]$. Our patient died prior to normal peak concentrations post-oral ingestion, suggesting that the postmortem blood level may not represent all of the amlodipine ingested by the child. Previous reports of the amounts ingested in adult fatalities range from 70 to $140 \mathrm{mg}$; however, the dose ingested in four of six cases is unknown. The reported ingested dose in surviving patients ranges widely from 50 to $1,000 \mathrm{mg}$. A recent study recommends that any child under the age of 6 with an ingestion of amlodipine greater than $2.5 \mathrm{mg}$ should be seen in the ED [3].

Two features of note in this case are the delay in presentation and the rapid cardiovascular collapse. It is unclear if earlier presentation would have allowed GI decontamination procedures such as activated charcoal to reduce absorption of the amlodipine or high-dose insulin therapy to be effective. The reported cases of survivors of amlodipine overdose were treated with aggressive fluid support as well as early vasopressor initiation [13-15]. Therapy for CCB toxicity has not been well established $[18,19]$. Due to the lipophilic nature of amlodipine, lipid emulsion rescue therapy may have a role in future therapy. Lipid emulsion therapy has been used successfully in another lipid-soluble $\mathrm{CCB}$ verapamil in the presence of arrhythmias and refractory hypotension [20-22].

A number of features in this case are supportive of amlodipine as the primary cause of death. The initial hyperglycemia is suggestive of a calcium channel antagonist suppression of insulin release. The initial metabolic acidosis is likely related to poor peripheral perfusion with subsequent lactate production. The tachycardia on presentation was likely a reflex cardiac response to initial peripheral vasodilatation, which ultimately progressed to bradycardia with refractory hypotension. Finally, the case presentation and postmortem blood levels are consistent with previous amlodipine ingestions [6-11]. While benazepril was a coingestant, we believe it was not a significant factor. There have been no previous reports of bradycardia with refractory hypotension in children from benazopril or other ACE inhibitors.

In summary, we report a case of rapid cardiovascular collapse and fatal outcome after amlodipine ingestion in an infant. Small doses of amlodipine (0.9 to $4.1 \mathrm{mg} / \mathrm{kg}$ ) may produce rapid and fatal cardiovascular collapse in an infant.

Conflict of interest The authors report no conflict of interest.

\section{References}

1. Faulker JK, McGibney D, Chasseaud LF, Perry JL, Taylor IW (1986) The pharmacokinetics of amlodipine in healthy volunteers after single intravenous and oral doses and after 14 repeated oral doses given once daily. Brit J Clin Pharmacol 22:21-25

2. Adams BD, Browne WT (1998) Amlodipine overdose causes prolonged calcium channel blocker toxicity. Am J Emerg Med 16:527-528

3. Benson BE, Spyker DA, Troutman WG, Watson WA, Bakhireva LN (2010) Amlodipine toxicity in children less than 6 years of age: a dose-response analysis using national poison data system data. $\mathrm{J}$ Emerg Med 39:186-193

4. Howarth DM, Dawson AH, Smith AJ et al (1994) Calcium channel blocking drug overdose: an Australian series. Hum Exp Toxicol 13:161-166

5. Belson MG, Gorman SE, Sullivan K, Geller RJ (2000) Calcium channel blocker ingestions in children. Am J Emerg Med 18:581586

6. Cosbey SH, Carson DJL (1997) A fatal case of amlodipine poisoning. J Anal Toxicol 21:221-222

7. Johansen SS, Grenner J (2003) A fatal case of amlodipine poisoning. J Clin Forensic Med 10:169-172

8. Koch AR, Vogalaers DP, Decruyenaere JM, Callens B, Verstraete A, Buylaert WA (1995) Fatal intoxication with amlodipine. Clin Toxicol 33:253-256

9. Linnet K, Lang LM, Johansen SS (2011) Postmortem femoral blood concentrations of amlodipine. J Anal Toxicol 35:227-231

10. Sklerov JH, Levine B, Ingwersen Aronica-Pollack PA, Fowler D (2006) Two cases of amlodipine overdose. J Analyt Toxicol 30:346-350 
11. Johansen SS, Genner J (2003) A fatal case of amlodipine poisoning. J Clin Forensic Med 10:169-172

12. Williams DM, Cubeddu L (1988) Amlodipine pharmacokinetics in healthy volunteers. J Clin Pharm 28:990-994

13. Paggenborg RP, Videbaek L, Jacobsen IA (2006) A case of amlodipine overdose. Basic Clin Pharmacol Toxicol 99:209-212

14. Vogt S, Mehlig A, Hunziker P, Hunziker P (2006) Survival of severe amlodipine intoxication due to medical intensive care. Foren Sci Internat 161:216-220

15. Stanek EJ, Nelson CE, DeNofrio D (1997) Amlodipine overdose. Ann Pharmacother 31:853-855

16. Ezidiegwu C, Spektor Z, Nasr MR, Kelly KC, Rosales LG (2008) A case report on the role of plasma exchange in management of a massive amlodipine besylate intoxication. Ther Apher Dial $12: 180-184$

17. Hilberg T, Rogde S, Morland J (1999) Postmortem drug redistribution - human cases related to results in experimental animals. J Forensic Sci 44:3-9
18. Ramoska EA, Spiller HA, Winter M, Borys D (1993) A one year evaluation of calcium channel blocker overdose: toxicity and treatment. Ann Emerg Med 85:361-366

19. Salhanick SD, Shannon MW (2003) Management of calcium channel antagonist overdose. Drug Saf 26:65-79

20. Franxman TJ, Al-Nabhan M, Cavallazzi RS, Speak AJ (2011) Lipid emulsion therapy for verapamil overdose. Ann Intern Med 154:292

21. Young AC, Valez LI, Kleinchmidt KC (2009) Intravenous fat emulsion therapy for intentional sustained-release verapamil overdose. Resuscitation 80:591-593

22. French D, Armenian P, Ruan W, Wong A, Drasner K, Olsen KR, Wu AHB (2011) Serum verpamil concentrations before and after intralipid therapy during treatment of an overdose. Clin Toxicol 49:340-344

23. Yuan TH, Kerns WP, Tomaszewski CA, Ford MD, Kline JA (1999) Insulin-glucose as adjuctive therapy for severe calcium channel antagonist poisoning. Clin Toxicol 37:463-474 